\title{
MATERIAL FLOW OPTIMIZATION THROUGH E-KANBAN SYSTEM SIMULATION
}

\author{
Pekarcikova, M.; Trebuna, P.; Kliment, M. \& Rosocha, L. \\ Technical University in Kosice, Faculty of Mechanical Engineering, Institute of Management, \\ Industrial and Digital Engineering, Nemcovej 32, 04200 Kosice, Slovakia \\ E-Mail: miriam.pekarcikova@tuke.sk, peter.trebuna@tuke.sk, marek.kliment@tuke.sk, \\ ladislav.rosocha@tuke.sk
}

\begin{abstract}
The digital evolution of lean thinking increases visibility along the whole value chain. It spreads and intensifies the potential of Supply Chain Collaboration in the network through the digitalization of orders, tracking deliveries and supplies in real-time, optimizing material and informational flows, and streamlining delivery time. Industry 4.0 transforms the business by creating a favourable environment for implementing well-known technologies from JIT/JIS and Kanban. The article aimed to map and create a simulation model of the production-assembly process and to propose the introduction of Kanban logic into material flow control. The implementation of the Kanban system and the testing of variant solutions using the simulation software Tecnomatix Plant Simulation made it possible to find the optimal solution.

(Received in February 2020, accepted in May 2020. This paper was with the authors 1 week for 1 revision.)
\end{abstract}

Key Words: E-Kanban, Modelling, Simulation, Visibility, Digitalization

\section{INTRODUCTION}

\subsection{Digital supply chain}

According to [1], European supply chain managers are talking about a key issue in digitization for their companies - IT integration. It is also reported that more than $80 \%$ of respondents expect the integration of IT systems and data within their group to offer significant, high, or very high potential to improve their supply chain, and $77 \%$ expect the same from IT networks with partner vendors and customers supply chain.
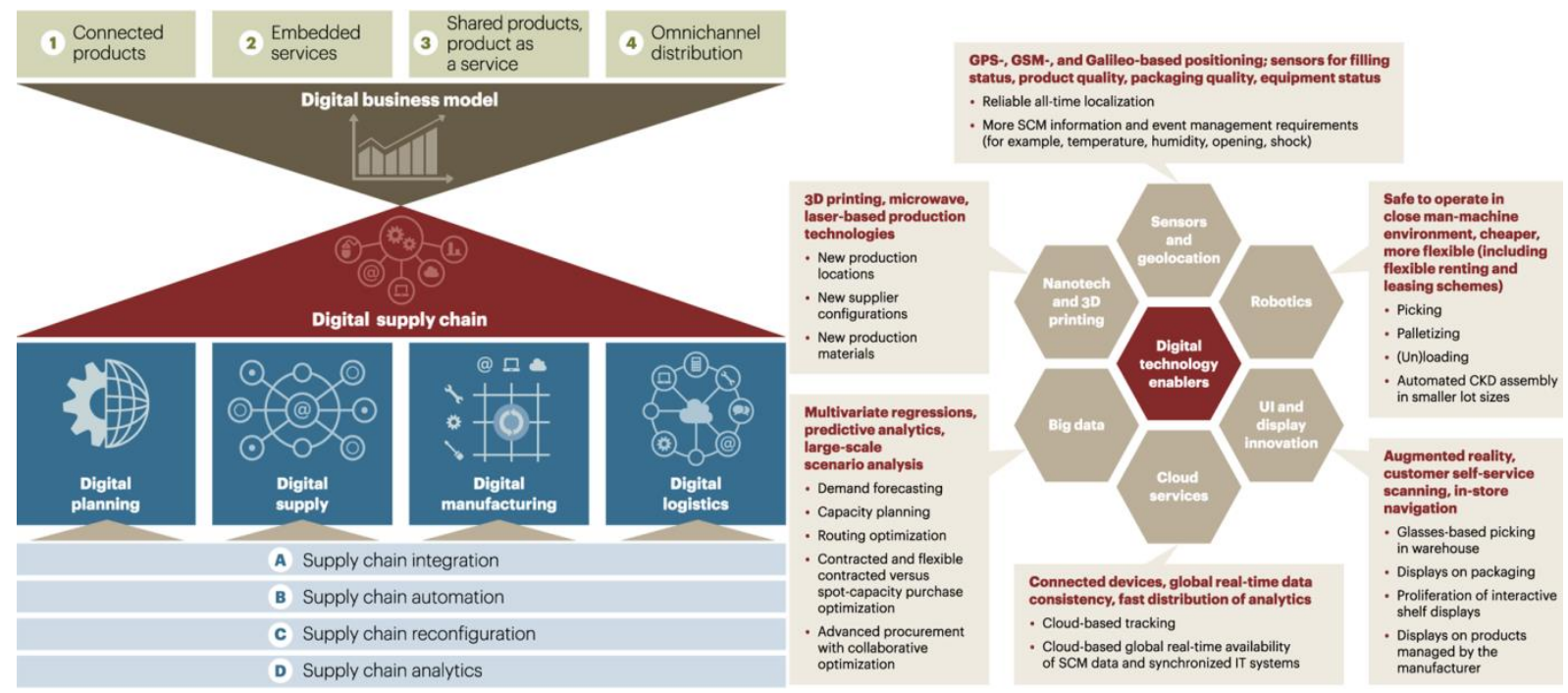

Figure 1: Digital SC framework (left), digital enablers, and select implications for SC (right) [2].

Businesses that invest intelligently and quickly in supply chain configurations can create a competitive advantage for the entire business model. Digital planning, digital delivery, digital 
production, and digital logistics can be included among the key dimensions of digital supply chain management (see Fig. 1).

However, achieving the optimum result is conditioned by a system solution. Globalization affects the design requirements of businesses, which must flexibly adapt to peak performance and ensure high production variability if they want to maintain a high degree of resilience to competitors. This production goal can be achieved by focusing on the modularity of the system concept supported by functional integration, the introduction of standardization, standardization in product design [3-6].

\subsection{The impact of Industry 4.0 on the Kanban concept}

The Kanban concept can be characterized as a turn-based inventory management system in an enterprise. The basic ideas are production to challenge and control the maximum level of inventory in the production system through a specified number of Kanban cards (or cartridges, containers). As it is strictly demand-oriented, relatively small production/transport batches mitigate the impact of the so-called bullwhip effect, which is one of the main challenges in supply chain management.

Kanban is suitable for low demand fluctuations and high product quality and delivery times. Flexible working time modifications are appropriate, as labour capacity should be coordinated according to actual production needs. In the traditional Kanban system, stock replenishment is oriented through the stock status, and the introduction of RFID technology will allow real-time stock monitoring. Instead of signalling material requirements via cards, resp. containers can be digitized using CPS/Cyber-physical system. This is the introduction of the so-called intelligent containers (iBin), which increase the flexibility of the supply system.

With the introduction of CPS, the Kanban concept aims to automate with limited and no human interaction, e.g. intelligent storage tanks operate on the principle of self-regulation, which contributes to the decentralization of the data collection and transfer process. The next phase concerning the coexistence of humans and robots is the question of creating fullyfledged autonomous robotized systems, where one will provide monitoring and control activities [7-10].

In this sense, the potential is created through:

- extension of applications such as e-Kanban, RFID technology, scanning devices with realtime signal transmission, full visibility of all processes that are part of the Kanban system,

- the introduction of an integrated camera system, containers equipped with CPS, which send data directly to the supplier,

- equipping Kanban tanks with sensors, which in real-time, in addition to monitoring the stock level, also monitor other data e.g. temperature, air pressure, vibration, dustiness (sensitive material),

- vertical integration in the enterprise information system,

- decentralized decision-making and self-regulation through CPS,

- virtualization and process simulation,

- the introduction of autonomous transport systems of supply (dynamic Milkrun) directly in the production hall,

- telematics units to enable the positioning of automatic conveyors in the system. 
Table I: Kanban concept in terms of Industry 4.0 technology implementation; adapted to [5-7, 10-14].

\begin{tabular}{|c|c|c|}
\hline Kanban: & \multicolumn{2}{|l|}{ Impact of Industry 4.0} \\
\hline process steps and activities & Scenarios & Options and components \\
\hline \begin{tabular}{|c|} 
Assessment of consumption \\
assessment of material requirements for \\
individual workplaces
\end{tabular} & $\begin{array}{l}\text { - real-time data collection and exchange } \\
\text { - triggering autonomous supply activities, e.g. replenishment of inventories, } \\
\text { initiation of drawing of reservoirs }\end{array}$ & $\begin{array}{l}\text { extension of applications such as e- } \\
\text { Kanban, RFID technology, scanning } \\
\text { devices with real-time signal } \\
\text { transmission, full visibility of all }\end{array}$ \\
\hline \begin{tabular}{|c|} 
Kanban signal \\
transmission of signals physically through \\
coded containers, resp. kanban cards
\end{tabular} & $\begin{array}{l}\text { - real-time digital information exchange } \\
\text { - signaling the need to add material directly at the supplier, } \\
\text { - Kanban signals released by the real needs of production, not on the set of the } \\
\text { supply cycle }\end{array}$ & $\begin{array}{l}\text { processes that are part of the Kanban } \\
\text { system } \\
\text { - implementation of an integrated } \\
\text { camera system, containers equipped }\end{array}$ \\
\hline $\begin{array}{c}\text { Production } \\
\text { supplier accepts kanban cards, resp. } \\
\text { tanks based on which to start production } \\
\text { in a predefined quantity }\end{array}$ & $\begin{array}{l}\text { - suppliers have real-time consumption information, } \\
\text { - starting production depends on exact requirements, which increases supply } \\
\text { chain flexibility to fluctuations in demand (which is a problem in the classic } \\
\text { Kanban system), } \\
\text { - shortening delivery cycles, } \\
\text { - minimal human interaction in the Kanban system }\end{array}$ & $\begin{array}{l}\text { with CPS, which send data directly to } \\
\text { the supplier, } \\
\text { - equipped with kanban tanks sensors, } \\
\text { which in real time in addition to } \\
\text { monitoring the level of inventory and } \\
\text { monitor other data e.g. temperature, }\end{array}$ \\
\hline $\begin{array}{l}\text { Collection and supply } \\
\text { use of Milkrun, i.e. creating supply } \\
\text { circuits with a fixed route, supplying at } \\
\text { fixed times with variable material } \\
\text { requirements determined by kanban } \\
\text { cards, resp. empty trays }\end{array}$ & $\begin{array}{l}\text { - efficient way of supply, due to the digitization of material flows. } \\
\text { - introduction of dynamic Milkrun for a wide range of materials and workplaces } \\
\text { with different production cycles, Milkrun will depend on demand not on time, } \\
\text { - the creation of modular systems within material flows, ensuring high flexibility } \\
\text { and autonomous supply }\end{array}$ & $\begin{array}{l}\text { - vertical integration in enterprise } \\
\text { information system, } \\
\text { - decentralized decision-making, self- } \\
\text { regulation through CPS, } \\
\text { - process virtualization and simulation } \\
\text { - introduction of autonomous }\end{array}$ \\
\hline \begin{tabular}{|c|} 
Receipt of material \\
customer receives and controls the input \\
material
\end{tabular} & $\begin{array}{l}\text { - information and communication technologies will facilitate the process of } \\
\text { material reception and eliminate human interaction, } \\
\text { - introduction of technologies so-called gate control systems that automatically } \\
\text { identify input material concerning the order, } \\
\text { - in case of disagreements, the responsible employee is immediately informed } \\
\text { via mobile phone, resp. the tablet connected to ERP system }\end{array}$ & $\begin{array}{l}\text { transport systems of supply (dynamic } \\
\text { Milkrun) directly in the production } \\
\text { hall, } \\
\text { - telematics units enable tracking of } \\
\text { the position of automatic conveyors } \\
\text { in the system }\end{array}$ \\
\hline
\end{tabular}

\section{E-KANBAN SYSTEM USING THE SIMULATION MODELS IN TX PLANT SIMULATION}

The E-Kanban system is based on a virtual system in which the card is not tangible but is transmitted by an electronic signal to the supplier. The electronic request is automatically generated and sent to the vendor indicating the required quantity of products. Many of the required products are processed as a request, which is created using a barcode or a more modern QR code, which is found on all necessary components. The system uses software applications to create orders. An ideal type of Kanban system is E-Kanban, whose task is to track a certain amount of material that has been consumed or pulled by an electronic signal. The signal is sent directly to internal or external subcontractors. For these suppliers, the order is automatically processed, where the same item is replaced in the required quantity to be delivered within the agreed time. Electronic Kanban differs from classic Kanban in that it replaces Kanban cards with barcodes. It uses technology to improve the movement of material within production.

\subsection{Modelling and simulation the E-Kanban using Tecnomatix Plant Simulation}

Kanban system in the term of Tx Plant Simulation is consumption regulated job control in the area of self-regulating loops created between each successive step in the material flow. To create an effective Kanban system is important to [15]:

- create linked self-regulating control loops between producer and customer,

- implement a pick-up principle for each subsequent consumption level,

- use the flexibility of workers and resources,

- transfer a short-term control to the executive staff,

- use a special Kanban card or containers to transfer information.

It is possible to make changes in these modular libraries are open for changes so that the user can modify them to meet the specific requirements. These modular libraries allow very efficiently creating the simulation models suitable for solving the problem of branches of 
industrial practice. The simulation is created using individual frames, as Tx Plant Simulation is software that supports a hierarchical approach to model creation. After clicking on the selected frame, the individual machines are displayed. The illustration is shown in Fig. 2. When creating the simulation, it is necessary to create a basic frame (master), in which the individual Frames (machines and manual workstation) are subsequently stored.

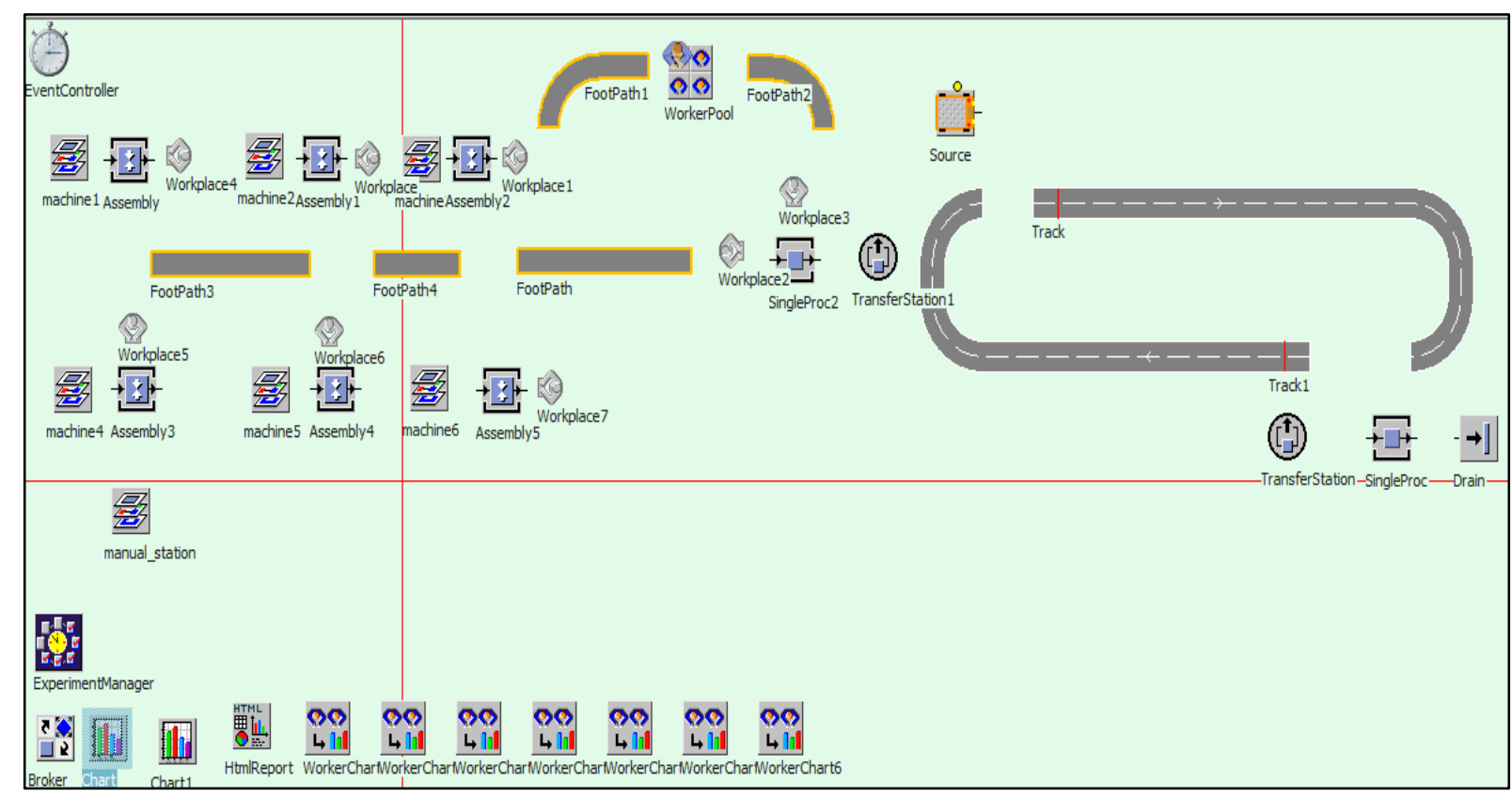

Figure 2: Simulation with Kanban system.

E-Kanban System advantages [15-17]:

- "real-time" availability of all relevant Kanban information and online in the Cloud,

- automated Kanban loops allows sent and visible the signals in real-time and on the screen immediately,

- minimal effort with the fast print of Kanban cards and capture of Kanban movements,

- low effort for the IT department and low maintenance costs,

- visualization and control of all Kanban information in real-time, pull control available through E-Kanban boards,

- available in different languages,

- analysis and optimization - inventory levels and delivery lead-times optimization based on historical data; Kanban levels adjustment based on variation in demand - the potential for optimizations.

\section{CASE STUDY}

\subsection{Description of the production process}

The case study was based on input data from a selected company whose main activity is the manufacture of medical devices. The company manufactures several second products that are used every day not only in the healthcare sector but also in the patient's home environment. The input material is tubing, foil, inlet valve, and boxes with appropriate instructions for the product. The output product is finished urinal collection bags. There are machines in the production process that use PLC systems designed to control machines. The machine works based on sliding parts that feed the foil, hose, and valve with a given dimension into a pressing form, which must have the exact dimensions of the urinal collecting bag. The design 
of each form must match the specific type of urinal collection bag produced. The machine producing the above products works on the principle of a press using which it welds and cuts the foil together with the tube in a 10-second interval. Next to the machine is an input material which is inserted into the machine using a lifting tool.

Another part of the production is a manual workplace where valves for the machines are produced and then used in the production process. The valves are manufactured using a manual lever press. The valve consists of two parts, the lower part of the valve and the upper part of the so-called valve housing. When both parts are inserted into the movement, a valve is formed by pressing. There are several jobs in the workplace such as production operator, supplier, quality manager, and shift master. Two production operators work on one machine.

The first operator services the machine, exchanges the material, set the necessary dimensions and tests for damage that may occur on the final product (e.g. damaged weld, insufficiently welded tube). The second operator carries out the packaging of the products in boxes and at the same time performs a visual inspection of the individual products. After the packaging process, the operator inserts instructions for product use. During the manufacturing process that is in progress on the machine, mutual assistance between production operators is possible. In the event of a serious machine failure, operators leave for a manual workstation where time can be compensated for by producing valves. Operators change every shift so that the work is not monotonous. They are ranked by their shift master for a particular machine.

\subsection{Creating a simulation model in Tx Plant Simulation}

The proposed model was elaborated based on layout and data from a real functioning production line (process times, machines, containers, workers, output products, etc.). The Assembly icon was used to model the machines and packaging. Assembly station is designed for joining individual parts or adding components to the assembled part. It allows the simulation of assembly processes. Simulation of the production line in $2 \mathrm{D}$ - the initial state is processed in Fig. 3. Input information on the manufacturing process is in Table II.

Table II: Input information of manufacturing process.

\begin{tabular}{|c|c|c|c|c|}
\hline Process & $\begin{array}{c}\text { Cycle time } \\
\text { (DDD:HH:MM:SS.XXX) }\end{array}$ & $\begin{array}{c}\text { Set-up time } \\
\text { (MM:SS.XXX) }\end{array}$ & $\begin{array}{c}\text { Availability } \\
\text { (\%) }\end{array}$ & $\begin{array}{c}\text { MTTR } \\
\text { ( MM:SS.XXX) }\end{array}$ \\
\hline drumming & $1: 15: 00$ & $0: 00.0000$ & 100 & 0.0000 \\
\hline crowding out & $4: 40: 00-4: 55: 00$ & $10: 00.0000$ & 95 & $5: 00.0000$ \\
\hline checking the diameter & $2: 00$ & $0: 00.0000$ & 100 & 0.0000 \\
\hline cabling & $3: 10: 00-3: 20: 00$ & $10: 00.0000$ & 95 & $5: 00.0000$ \\
\hline splicing & $2: 15: 00-2: 25: 00$ & $10: 00.0000$ & 95 & $5: 00.0000$ \\
\hline coil packing & $6: 00$ & $0: 00.0000$ & 100 & 0.0000 \\
\hline check cords & $11: 00$ & $0: 00.0000$ & 100 & 0.0000 \\
\hline pallet packaging & $9: 00$ & $0: 00.0000$ & 100 & 0.0000 \\
\hline shipping & $15: 00$ & $0: 00.0000$ & 100 & 0.0000 \\
\hline
\end{tabular}

Its processing times are set using Table file, which is in the 10 -second interval and the package is set to 5 minutes. Another item is to create entities that will be produced. Each machine produces a different product, divided by entities. The products are divided into entities for children bags, valve bags, bed bags, travel bags, disposable bags. The manual workstation will produce valves that are weighed gradually to specific machines.

Using the Event Controller sets the time of one change, which lasts 12 hours. Production is carried out by the following system, where the machine enters the foil with tubing. The welding process takes place in the machine and the moulding is then placed on a sliding belt which is moved towards the packaging. In the package, the worker performs a visual inspection and gradually puts it into a box of 25 bags, which form one bundle. Subsequently, 8 of these bundles are placed in one box. 200 bags are placed in one box. After packing in 
boxes, the boxes are weighed into intermediate storage. The products are again removed from the intermediate warehouse to the main warehouse, where they are shipped to a specific customer.

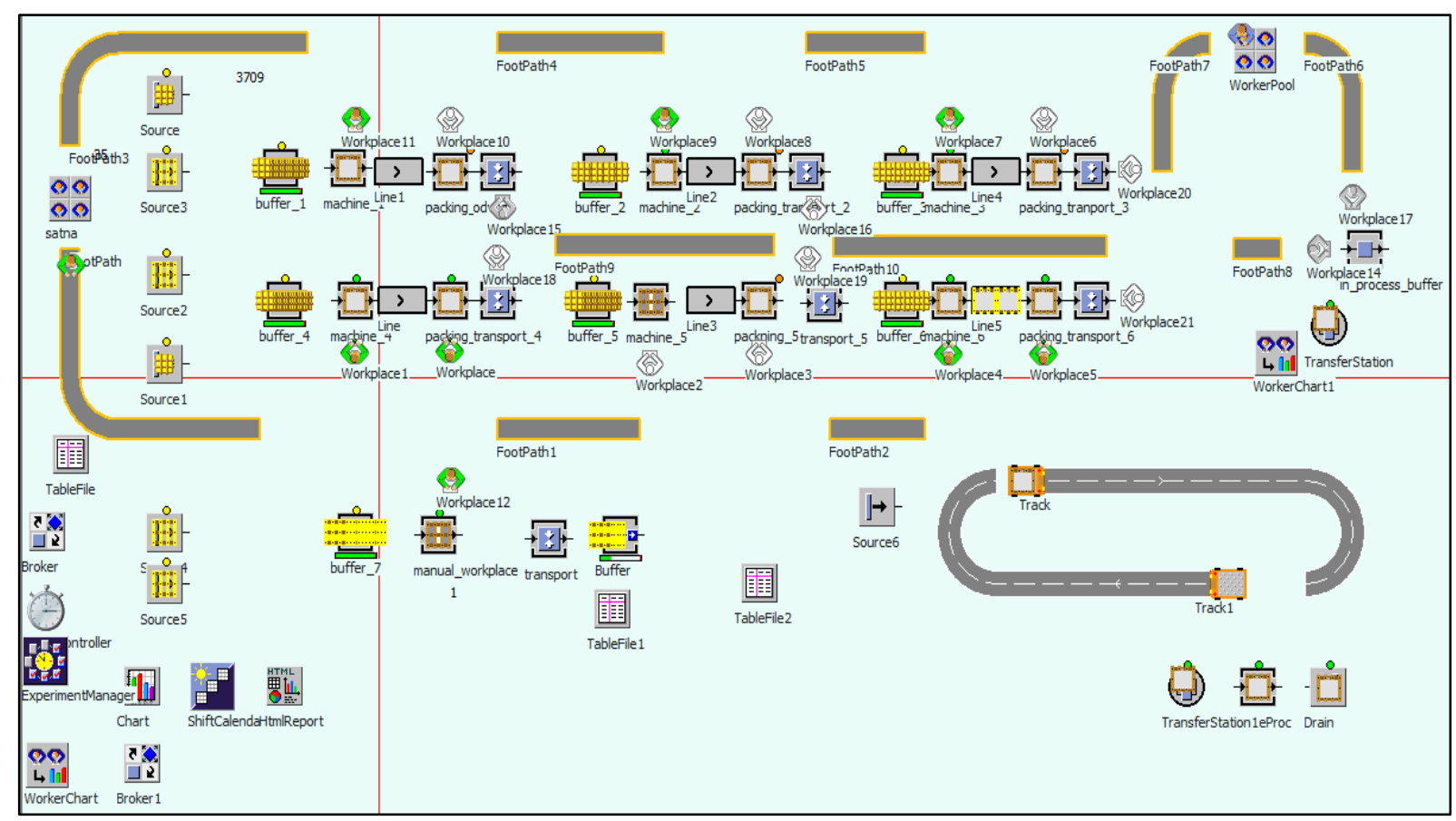

Figure 3: Simulation of the production line in $2 \mathrm{D}$ - initial state.

One way to analyse the entire system is through the Experiment Manager icon. Experiment Manager lets you run multiple experiments at once. The Experiment Manager performs different simulations during the experiment and provides the results of these experiments when finished. At the end of the experiment, an overall analysis is displayed, showing min. and max. final products (see Fig. 4).

\subsection{Simulation model of E-Kanban in Tx Plant Simulation}

After reviewing the values, as many products as are required are not produced. One way to increase production efficiency is to introduce an E-Kanban system. Kanban is a well-known Japanese management system whose management is based on the use of cards with different colours to indicate stock levels and production. The main benefit of the Kanban system is to reduce inventory without major investment while ensuring the most perfect production process. The E-Kanban system is based on a virtual system in which the card is not tangible but is transmitted by an electronic signal to the supplier. The electronic request is automatically generated and sent to the vendor indicating the required quantity of products. Many of the required products are processed as a request, which is created using a barcode or a more modern QR code, which is found on all necessary components.

The system uses software applications to create orders. The ideal type of Kanban system is E-Kanban, whose task is to track a certain amount of material that has been consumed or pulled by an electronic signal. The signal is sent directly to internal or external subcontractors. For these suppliers, the order is automatically processed, where the same item is replaced in the required quantity to be delivered within the agreed time. Electronic Kanban differs from classic Kanban in that it replaces Kanban cards with barcodes. It uses technology to improve the movement of material within production $[18,19]$. 
Pekarcikova, Trebuna, Kliment, Rosocha: Material Flow Optimization through E-Kanban ...

\section{Overview}

Overview of all executed experiments, their parametrizations and the mean values of the target values.

\begin{tabular}{|r|r|r|r|}
\hline & Capacity of Buffer & Capacity of Zasobnik4 & Throughput \\
\hline Exp 01 & 5 & 5 & 261 \\
\hline $\operatorname{Exp} 02$ & 5 & 10 & 261 \\
\hline $\operatorname{Exp} 03$ & 5 & 15 & 261 \\
\hline $\operatorname{Exp} 04$ & 5 & 20 & 261 \\
\hline $\operatorname{Exp} 05$ & 5 & 25 & 261 \\
\hline $\operatorname{Exp} 06$ & 10 & 5 & 267.5 \\
\hline $\operatorname{Exp} 07$ & 10 & 10 & 267.5 \\
\hline $\operatorname{Exp} 08$ & 10 & 15 & 267.5 \\
\hline $\operatorname{Exp} 09$ & 10 & 20 & 267.5 \\
\hline $\operatorname{Exp} 10$ & 10 & 25 & 267.5 \\
\hline $\operatorname{Exp} 11$ & 15 & 5 & 370.5 \\
\hline $\operatorname{Exp} 12$ & 15 & 10 & 370.5 \\
\hline $\operatorname{Exp} 13$ & 15 & 15 & 370.5 \\
\hline $\operatorname{Exp} 14$ & 15 & 20 & 370.5 \\
\hline $\operatorname{Exp} 15$ & 15 & 25 & 370.5 \\
\hline $\operatorname{Exp} 16$ & 20 & 5 & 378 \\
\hline $\operatorname{Exp} 17$ & 20 & 10 & 378 \\
\hline $\operatorname{Exp} 18$ & 20 & 15 & 378 \\
\hline $\operatorname{Exp} 19$ & 20 & 20 & 378 \\
\hline $\operatorname{Exp} 20$ & 20 & 25 & 378 \\
\hline $\operatorname{Exp} 21$ & 25 & 5 & 345 \\
\hline $\operatorname{Exp} 22$ & 25 & 10 & 345 \\
\hline $\operatorname{Exp} 23$ & 25 & 15 & 345 \\
\hline $\operatorname{Exp} 24$ & 25 & 20 & 345 \\
\hline $\operatorname{Exp} 25$ & 25 & 25 & 345 \\
\hline
\end{tabular}

Values of experiments

Input values (Model parameters)

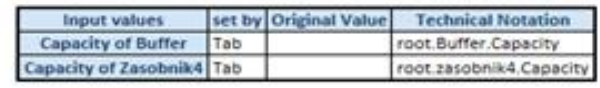

The input values are set by either the Table ExpTable or by actions of rules.

Output values (Results of the simulation study)

\begin{tabular}{|l|l|l|}
\hline Target value & evaluated by & Technical Notation \\
\hline Throughput & Tab & roor. Drain.statNumin \\
\hline
\end{tabular}

The Output values are evaluated by the table ResultsTable or by conditions of rules.

Multi-level experimental design

Design table of the experiment study

Simulaton effort: 25 experiments with 50 simulation runs.

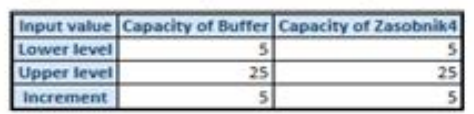

\section{Statistical Evaluations}

- Statistical rellabality

Observatsas per experimeat: 2

Confidesce lovel (9h): 95

【Statistics of output values

|Evaluations of the output value 'Throughput'
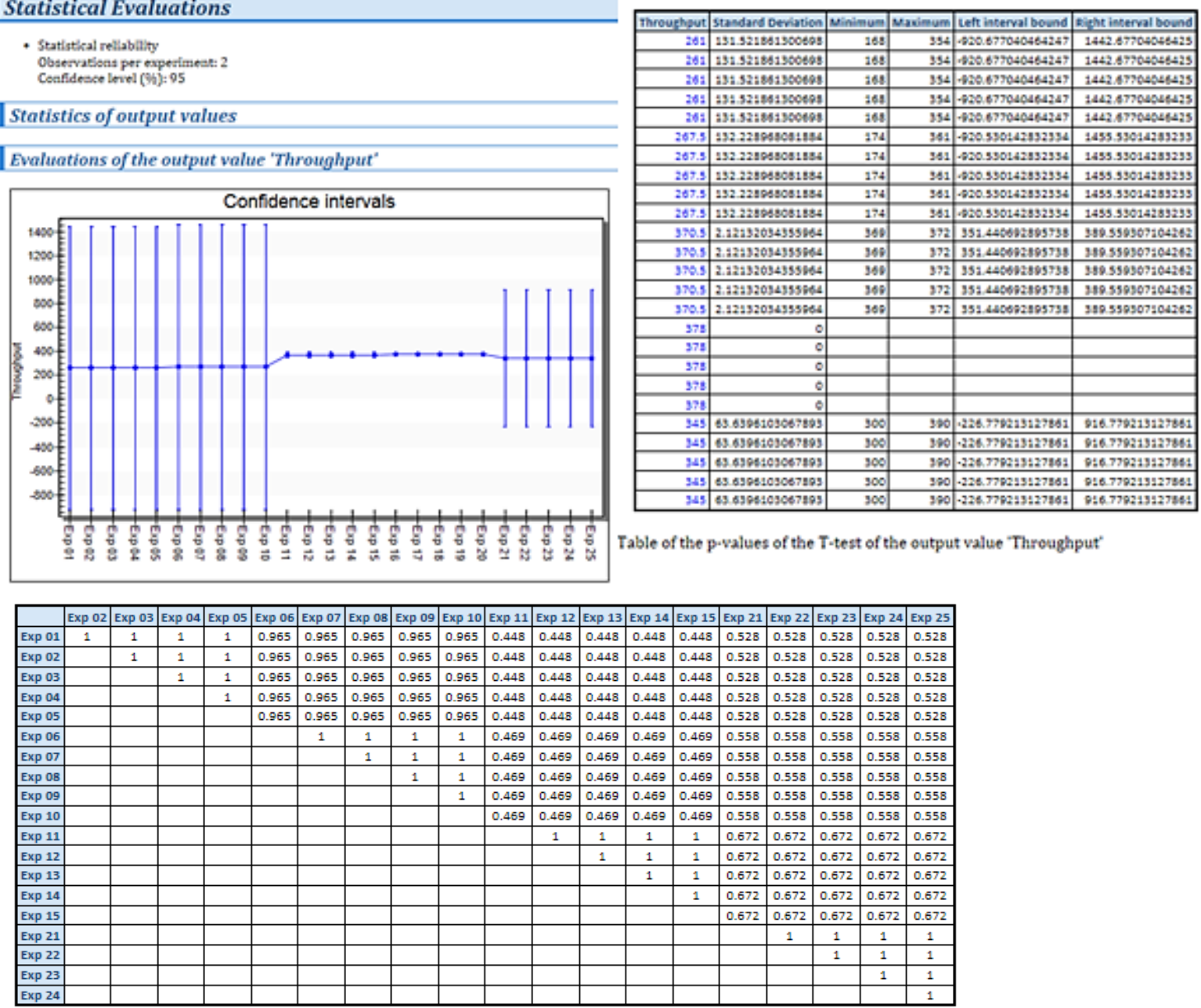

If the $p$-value is smaller than a given level of significance (probability of error, for instance 0.05 ),

then we can presume that the mean values are different with a probability of $95 \%$.

You can view the p-values for all pairs of experiments by selecting Tools > Analysis of Variance in the dialog of the ExperimentManager.

Figure 4: Total view of experiment statistics - Experiment manager. 
The simulation is created using individual frames since the software supports a hierarchical modeling approach. After clicking on the selected frame, the individual machines are displayed. The illustration is shown in Fig. 5. When creating a simulation, it is necessary to create a basic frame (master), in which the individual frames (machines and manual workstation) are subsequently stored.

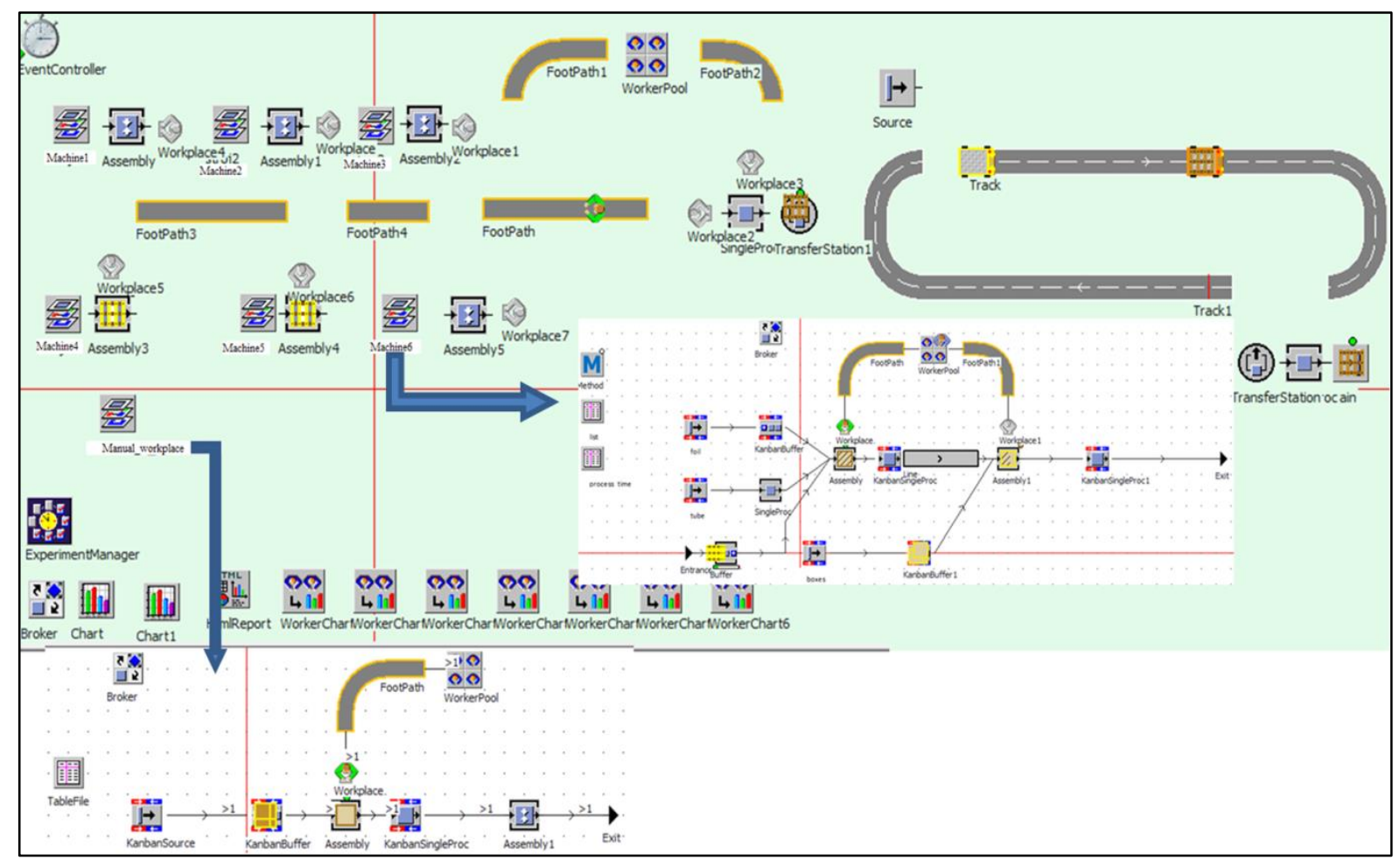

Figure 5: Simulation model of the E-Kanban system with the illustration of selected frames - proposed state.

To create individual machines it is necessary to select the item Kanban from the Manage Class Library and then in tools, it is necessary to select the elements that control the machines. The Kanban input and Kanban buffer are set using Table File and Method. The role of these features is to control the input of plastic foils. The tubing inlet is set using Kanban Singl Proc, which is used to order the tubing. The selected setting is for the machine that enters the foil and tubing at the process interval as in the previous simulation with given process times. The formed bags proceed along the conveyor belt to Assembly 1, where they are subsequently packed. Input packs are bags and cartons that are pulled using Kanban singl proc from Kanban buffer. The buffer function secures the boxes by the pull principle from the Kanban Source input. The created machine in the frame must be terminated by output using the Interface function, which is needed to connect to the mainframe through which products are shipped to Drain.

The whole simulation is carried out using the thrust principle that controls the Kanban single proc. Kanban singl proc is set to a processing time that is zero (no production delay). Its function is to order material. The simulation is set to a 12-hour change that only works as a whole. This means that individual frames are not functional separately (they cannot be run separately), only as a whole. The Worker Chart function must be specified for each frame separately because of the use of multiple frames. The simulation procedure and output statistics are shown in Fig. 6. 
Pekarcikova, Trebuna, Kliment, Rosocha: Material Flow Optimization through E-Kanban ...

\section{Statistics}

\section{State Statistics}

\begin{tabular}{|l|r|r|r|r|r|r|r|r|r|r|}
\hline \multicolumn{1}{|c|}{ Object } & Working & Set-up & Waiting & Blocked & Powering up/down & Failed & Stopped & Paused & Unplanned & Portion \\
\hline Drain & $69.63 \%$ & $0.00 \%$ & $30.37 \%$ & $0.00 \%$ & $0.00 \%$ & $0.00 \%$ & $0.00 \%$ & $0.00 \%$ & $0.00 \%$ & \\
\hline Track & $4.29 \%$ & $0.00 \%$ & $95.71 \%$ & $0.00 \%$ & $0.00 \%$ & $0.00 \%$ & $0.00 \%$ & $0.00 \%$ & $0.00 \%$ & \\
\hline Track1 & $3.90 \%$ & $0.00 \%$ & $96.10 \%$ & $0.00 \%$ & $0.00 \%$ & $0.00 \%$ & $0.00 \%$ & $0.00 \%$ & $0.00 \%$ & \\
\hline Source & $0.00 \%$ & $0.00 \%$ & $97.12 \%$ & $2.88 \%$ & $0.00 \%$ & $0.00 \%$ & $0.00 \%$ & $0.00 \%$ & $0.00 \%$ & \\
\hline SingleProc & $69.77 \%$ & $0.00 \%$ & $30.23 \%$ & $0.00 \%$ & $0.00 \%$ & $0.00 \%$ & $0.00 \%$ & $0.00 \%$ & $0.00 \%$ & \\
\hline TransferStation & $69.91 \%$ & $0.00 \%$ & $30.09 \%$ & $0.00 \%$ & $0.00 \%$ & $0.00 \%$ & $0.00 \%$ & $0.00 \%$ & $0.00 \%$ & \\
\hline SingleProc2 & $70.68 \%$ & $0.00 \%$ & $29.32 \%$ & $0.00 \%$ & $0.00 \%$ & $0.00 \%$ & $0.00 \%$ & $0.00 \%$ & $0.00 \%$ & \\
\hline WorkerPool & $0.00 \%$ & $0.00 \%$ & $91.07 \%$ & $8.93 \%$ & $0.00 \%$ & $0.00 \%$ & $0.00 \%$ & $0.00 \%$ & $0.00 \%$ & \\
\hline TransferStation1 $170.56 \%$ & $0.00 \%$ & $29.44 \%$ & $0.00 \%$ & $0.00 \%$ & $0.00 \%$ & $0.00 \%$ & $0.00 \%$ & $0.00 \%$ & \\
\hline Assembly & $0.00 \%$ & $0.00 \%$ & $97.87 \%$ & $2.13 \%$ & $0.00 \%$ & $0.00 \%$ & $0.00 \%$ & $0.00 \%$ & $0.00 \%$ & \\
\hline Assembly1 & $0.00 \%$ & $0.00 \%$ & $65.12 \%$ & $34.88 \%$ & $0.00 \%$ & $0.00 \%$ & $0.00 \%$ & $0.00 \%$ & $0.00 \%$ & \\
\hline Assembly2 & $0.00 \%$ & $0.00 \%$ & $88.96 \%$ & $11.04 \%$ & $0.00 \%$ & $0.00 \%$ & $0.00 \%$ & $0.00 \%$ & $0.00 \%$ & \\
\hline Assembly3 & $0.00 \%$ & $0.00 \%$ & $79.87 \%$ & $20.13 \%$ & $0.00 \%$ & $0.00 \%$ & $0.00 \%$ & $0.00 \%$ & $0.00 \%$ & \\
\hline Assembly4 & $0.00 \%$ & $0.00 \%$ & $95.77 \%$ & $4.23 \%$ & $0.00 \%$ & $0.00 \%$ & $0.00 \%$ & $0.00 \%$ & $0.00 \%$ & \\
\hline Assembly5 & $0.00 \%$ & $0.00 \%$ & $91.64 \%$ & $8.36 \%$ & $0.00 \%$ & $0.00 \%$ & $0.00 \%$ & $0.00 \%$ & $0.00 \%$ & \\
\hline
\end{tabular}

Portions of the States

\section{Simulation time: 12:00:00.0000}

\begin{tabular}{|l|l|r|r|r|r|r|r|r|r|}
\hline Cbject & \multicolumn{1}{|c|}{ Name } & Mean Life Time & Throughput & TPH & Production & Transport & Storage & Value added & Portion \\
\hline Drain & Travel_bags & $12: 58.6935$ & 76 & 6 & $37.72 \%$ & $62.28 \%$ & $0.00 \%$ & $23.12 \%$ & \\
\hline Drain & Baby_bags & $14: 00.8859$ & 87 & 7 & $38.02 \%$ & $61.98 \%$ & $0.00 \%$ & $21.41 \%$ & \\
\hline Drain & Disposable_bags & $11: 45.3225$ & 87 & 7 & $28.58 \%$ & $71.42 \%$ & $0.00 \%$ & $25.52 \%$ & \\
\hline Drain & Bed_bags & $11: 52.9818$ & 88 & 7 & $32.76 \%$ & $67.24 \%$ & $0.00 \%$ & $25.25 \%$ & \\
\hline Drain & Bags_with_valves & $12: 55.3605$ & 76 & 6 & $33.16 \%$ & $66.84 \%$ & $0.00 \%$ & $23.22 \%$ & \\
\hline Drain & Bags_with_hanger & $14: 41.8651$ & 87 & 7 & $41.18 \%$ & $58.82 \%$ & $0.00 \%$ & $20.41 \%$ & \\
\hline
\end{tabular}

Figure 6: Total view of simulation statistics after the second simulation run.

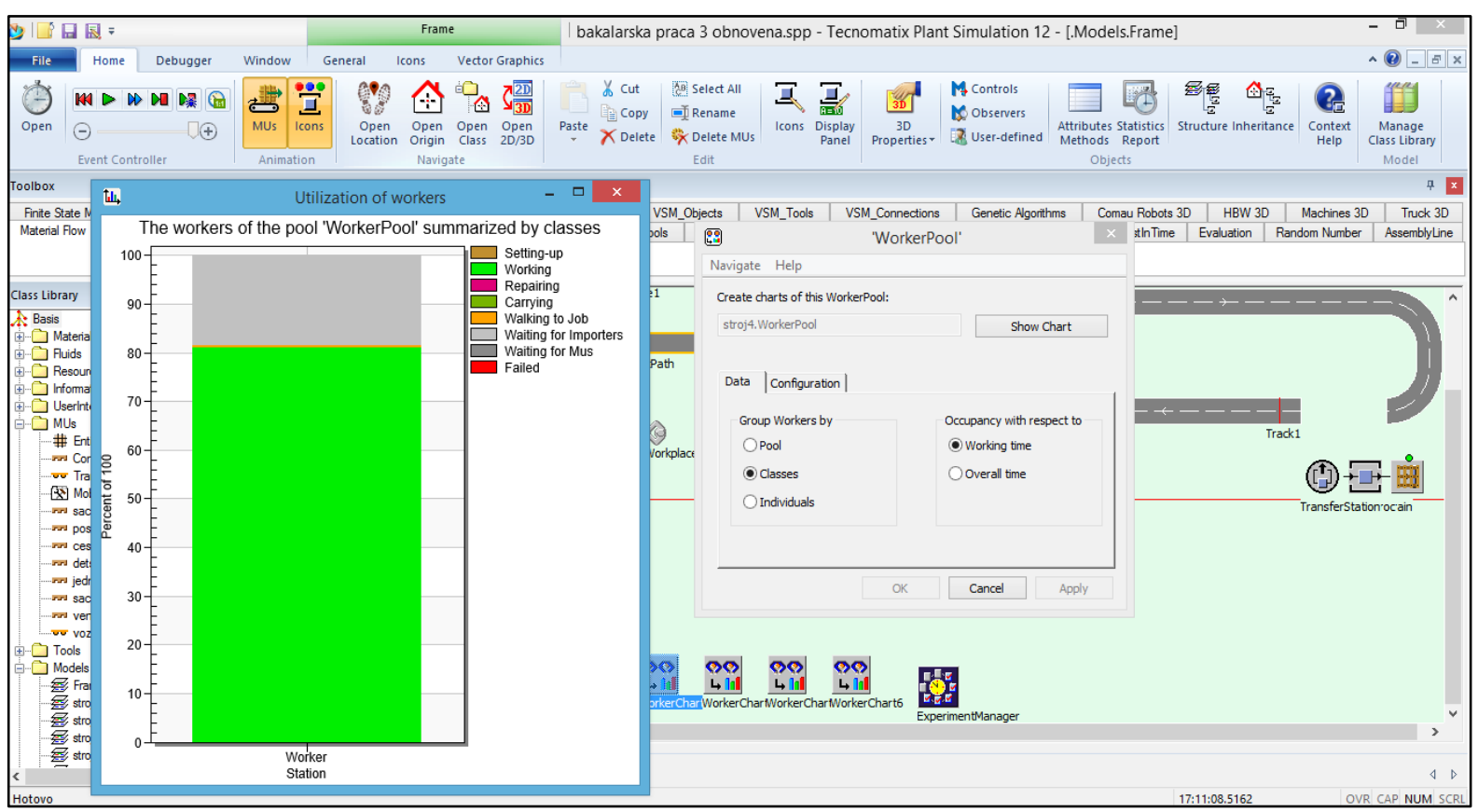

Figure 7: Use of operators during the working shift. 
In this simulation, statistics are shown for only one frame. This statistic only shows product pick-up and total boxes produced. The above statistics show that for bags in which valves are used for their production (travel bags, bags with valves) there is a smaller quantity of pieces (boxes) produced. In the simulation with Kanban system, we can see an increase in the number of boxes produced compared to the previous simulation, for example, 87 disposable bags were produced in 12-hour change, which means that 17400 bags were packed. For machine statistics, it is necessary to enter the Html report in all frame machines where it is necessary to play the whole simulation. The statistics will only show the statistics of the percentage utilization of machines. The use of operators during the working shift is shown in Fig. 7.

\section{CONCLUSION AND OUTLOOK}

The simulations were created with the same processing times and the same arrangement of machines and workers. The first simulation, which was created from a real working company, used a toolbar with ordinary elements. To increase capacity, Experiment Manager was used to increase productivity only when using an additional supply or to set process times. Process times would lead to increased workload, which would harm product quality. Productivity increased by $23 \%$ after adding a reservoir. If there were two feeders, it would represent an increase in further investment. With the statistics shown, it is possible to observe an increase in the products in the second simulation using the E-Kanban system. The E-Kanban system has improved not only product growth but also machine utilization and working time.

Table III: Comparison of realized simulation runs.

\begin{tabular}{|c|c|c|c|c|c|c|}
\cline { 2 - 7 } \multicolumn{1}{c|}{} & $\begin{array}{c}\text { Travel } \\
\text { bags }\end{array}$ & Baby bags & $\begin{array}{c}\text { Disposable } \\
\text { bags }\end{array}$ & Bed bags & $\begin{array}{c}\text { Bags with } \\
\text { valves }\end{array}$ & $\begin{array}{c}\text { Bags with } \\
\text { hanger }\end{array}$ \\
\hline $\mathbf{1}^{\text {st }}$ simulation & 51 & 45 & 54 & 53 & 45 & 52 \\
\hline $\mathbf{2}^{\text {nd }}$ simulation & 76 & 88 & 87 & 87 & 76 & 87 \\
\hline Difference & $33 \%$ & $49 \%$ & $38 \%$ & $39 \%$ & $41 \%$ & $40 \%$ \\
\hline
\end{tabular}

Table III and Fig. 8 show the percentage difference between the two simulations. Using an E-Kanban system, production increased by an average of $40 \%$.

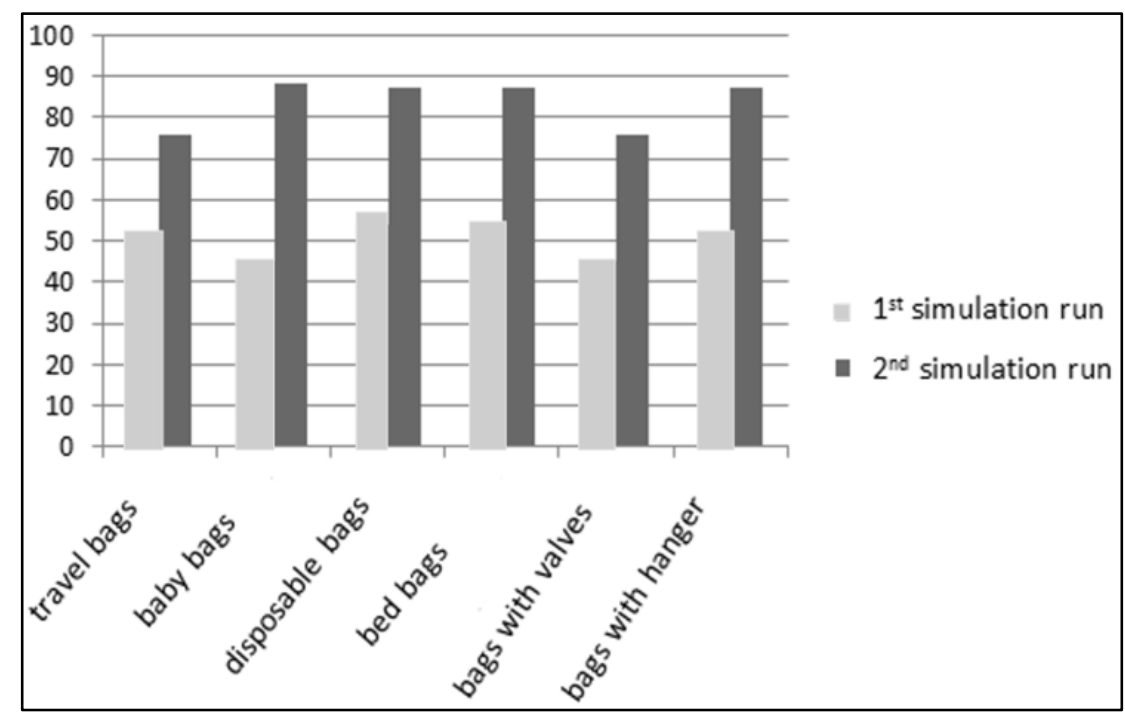

Figure 8: Graphical display after two simulation runs. 
Compared to the simulation, the operator load is also shown. In the first simulation, the average utilization is $68 \%$ and the second simulation moves with a utilization rate of $82 \%$. The second simulation points out that after the introduction of Kanban the performance increased by $14 \%$ while maintaining the same process times. The introduction of the EKanban system directs production towards a steady production, which results from statistics. The E-Kanban system produces the same number of bags produced, except for machines that use valves. The reason for delaying production on these machines is the more complicated procedure since the use of valves is required to produce bags. The simulation aimed to effectively increase the productivity of the finished products without changing the process times. The desired result was achieved using the E-Kanban system in the second simulation. Traditional demand forecasting and scheduling tools are unable to flexibly synchronize supply and demand.

According to sources [10-12], Industry 4.0 will increase the complexity of supplycustomer networks, increasingly need to adapt to the customer, and respond at a time that he is willing to accept while waiting for the product. The traditional perception of the supply chain as a linear system (stability and predictability) that enables the optimization of individual subsystems and thus obtains an optimized supply chain as a whole is no longer sufficient. The vision of the future is the self-regulation of enterprises, which will be based on the autonomous functioning and mutual communication of machines, mainly robots and products according to real-time information. Sensors will monitor the entire production process, system integration will enable customers to interact with the design and manufacturing process, increased machine and equipment availability, shorter production cycle times, faster response to customer requests due to self-regulation of entering transactions (without human interaction). Modern technologies based on cloud computing enable the transition from push systems to pull. This is because of working with information that is updated and supplemented daily [14, 18-24].

\section{ACKNOWLEDGEMENT}

This article was created by the implementation of the grant project APVV-17-0258 "Digital engineering elements application in innovation and optimization of production flows", VEGA $1 / 0438 / 20$ "Interaction of digital technologies to support software and hardware communication of the advanced production system platform" and KEGA 001TUKE-4/2020 "Modernizing Industrial Engineering education to Develop Existing Training Program Skills in a Specialized Laboratory".

\section{REFERENCES}

[1] TRACC. Continuous improvement: Will Industry 4.0 spell the end of lean manufacturing?, from https://traccsolution.com/blog/industry-4-0/, accessed on 10-02-2020

[2] Kearney. Digital supply chains: increasingly critical for competitive edge, WHU Logistics Study 2015, from https://www.atkearney.com/operations-performance-transformation/article?/a/digitalsupply-chains-increasingly-critical-for-competitive-edge, accessed on 10-02-2020

[3] Zivanic, D.; Zelic, A.; Lalic, B.; Simeunovic, N.; Szabo, L. (2019). Improving the order picking efficiency by optimising the orders' sequence, International Journal of Simulation Modelling, Vol. 18, No. 1, 125-137, doi:10.2507/IJSIMM18(1)469

[4] Chromjakova, F.; Bobak, R.; Hrusecka, D. (2017). Production process stability - core assumption of INDUSTRY 4.0 concept, $5^{\text {th }}$ International Conference on Manufacturing, Optimization, Industrial and Material Engineering, 143-154

[5] Kuperova, M.; Zatrochova, M. (2014). Logistics conceptions in the production management in small-and medium-sized industrial companies in the Slovak republic, Borkowski, S.; Ipavec, V. M. (Eds.), Toyotarity. Change Management, Aeternitas Publishing House, Alba Iulia, 135-146 
[6] Moon, S.; Ji, W.; Moon, H.; Kim, D. (2018). A simulation of order resonance phenomenon in a supply chain triggered by reinforcing loop, International Journal of Simulation Modelling, Vol. 17, No. 2, 231-244, doi:10.2507/IJSIMM17(2)421

[7] Rajnoha, R.; Galova, K.; Rozsa, Z. (2018). Measurement of impact of selected industrial engineering practices on companies' economic performance, Inzinerine Ekonomika Engineering Economics, Vol. 29, No. 2, 176-187, doi:10.5755/j01.ee.29.2.19871

[8] Micieta, B.; Edl, M.; Krajcovic, M.; Dulina, L.; Bubenik, P.; Durica, L.; Binasova, V. (2018). Delegate MASs for coordination and control of one-directional AGV systems: a proof-ofconcept, International Journal of Advanced Manufacturing Technology, Vol. 94, No. 1-4, 415431, doi:10.1007/s00170-017-0915-8

[9] Zhu, J.; Shao, Z. H.; Chen, C. (2019). An improved whale optimization algorithm for job-shop scheduling based on quantum computing, International Journal of Simulation Modelling, Vol. 18, No. 3, 521-530, doi:10.2507/IJSIMM18(3)CO13

[10] Bousonville, T. (2017). Logistik 4.0: Die digitale Transformation der Wertschöpfungskette, Springer Gabler, Wiesbaden

[11] Grant, D. B.; Trautrims, A.; Wong, C. Y. (2017). Sustainable logistics and supply chain management, $2^{\text {nd }}$ edition, Kogan Page, New York

[12] Hofmann, E.; Rüsch, M. (2017). Industry 4.0 and the current status as well as future prospects on logistics, Computers in Industry, Vol. 89, 23-34, doi:10.1016/j.compind.2017.04.002

[13] Grznar, P.; Gregor, M.; Mozol, S.; Krajcovic, M.; Dulina, L.; Gaso, M.; Major, M. (2019). A system to determine the optimal work-in-progress inventory stored in interoperation manufacturing buffers, Sustainability, Vol. 11, No. 14, Paper 3949, 36 pages, doi:10.3390/ $\underline{\text { su11143949 }}$

[14] Fedorko, G.; Vasil, M.; Bartosova, M. (2019). Use of simulation model for measurement of MilkRun system performance, Open Engineering, Vol. 9, No. 1, 600-605, doi:10.1515/eng-2019$\underline{0067}$

[15] Bangsow, S. (2015). Tecnomatix Plant Simulation. Modeling and Programming by Means of examples, Springer, Cham

[16] Zupancic, D.; Buchmeister, B.; Aljaz, T. (2017). Reducing the time of task execution with existing resources - comparison of approaches, International Journal of Simulation Modelling, Vol. 16, No. 3, 484-496, doi:10.2507/IJSIMM16(3)10.394

[17] Krajcovic, M.; Hancinsky, V.; Dulina, L.; Grznar, P.; Gaso, M.; Vaculik, J. (2019). Parameter setting for a genetic algorithm layout planner as a toll of sustainable manufacturing, Sustainability, Vol. 11, No. 7, Paper 2083, 26 pages, doi:10.3390/su11072083

[18] Stefanik, A.; Grznar, P.; Micieta, B. (2003). Tools for continual process improvement simulation and benchmarking, Proceedings of the $14^{\text {th }}$ International DAAAM Symposium, 443-444

[19] Ignacz, P. (2019). Use of digital tools in logistic and production facility management for effective information flow, Acta Logistica, Vol. 6, No. 4, 141-146, doi:10.22306/al.v6i4.141

[20] Straka, M.; Malindzak, D. (2009). Algorithms of capacity balancing of printing machineries for Alfa Foils, a.s. planning system, Acta Montanistica Slovaca, Vol. 14, No. 1, 98-102

[21] Straka, M.; Rosova, A.; Malindzakova, M.; Khouri, S.; Culkova, K. (2018). Evaluating the waste incineration process for sustainable development through modelling, logistics, and simulation, Polish Journal of Environmental studies, Vol. 27, No. 6, 2739-2748, doi:10.15244/pjoes/81062

[22] Pribulova, A.; Pokusova, M. (2019). Using a simulation programme to predict distortion of cast iron castings, Proceedings of the $19^{\text {th }}$ International Multidisciplinary Scientific GeoConference, 713-720, doi:10.5593/sgem2019/2.1/S07.093

[23] Istokovic, D.; Perinic, M.; Dobovicek, S.; Bazina, T. (2019). Simulation framework for determining the order and size of the product batches in the flow shop: A case study, Advances in Production Engineering \& Management, Vol. 14, No. 2, 166-176, doi:10.14743/apem2019.2.319

[24] Prester, J.; Buchmeister, B.; Palčič, I. (2018). Effects of advanced manufacturing technologies on manufacturing company performance, Strojniski vestnik - Journal of Mechanical Engineering, Vol. 64, No. 12, 763-771, doi:10.5545/sv-jme.2018.5476 